\title{
Rectal damage control: when to do and not to do
}

\section{Control de daños de recto: que hacer y que no hacer}

\author{
Luis Guillermo Saldarriaga1 ${ }^{(D)}$ Helmer Emilio Palacios-Rodríguez ${ }^{1}$ Luis Fernando Pino1,2 \\ Adolfo González Hadad ${ }^{1,2,3}$ Linda M. Gallego ${ }^{4}$ Jessica Capre ${ }^{5}$ Alberto García ${ }^{1,4,6}$ (D) \\ Fernando Rodríguez-Holguín ${ }^{5}$ Alexander Salcedo ${ }^{1,2,4,6}{ }^{(\mathbb{D}}$ José Julián Serna ${ }^{1,2,4,6}$ Mario \\ Alain Herrera ${ }^{1,2}$ (D) Michael W. Parra ${ }^{7}$ Carlos A. Ordoñez ${ }^{1,4,6}$ Abraham Kestenberg- \\ Himelfarb $^{5}$ (iD \\ ordonezcarlosa@gmail.com, carlos.ordonez@fvl.org.co
}

\section{OPEN ACCESS}

Citation: .Saldarriaga LG, PalaiosRodríguez HE, Pino LF, González HA, Caicedo Y, Capre J. CaicedoHolguín I, Galloego LM, García A, Rodríguez-Holguín F, Salcedo A, Serna JJ, Herrera MA, Parra MW, Ordoñez CA. Kestenberg-Himelfarb A. Rectal damage control: when to do and not to do. Colomb Méd (Cali), 2021; 52(2):e4124776 http://doi. org/10.25100/cm.v52i2.4776

$\begin{array}{ll}\text { Received : } & 15 \text { Mar } 2021 \\ \text { Revised: } & 21 \text { Apr } 2021 \\ \text { Accepted : } & 13 \text { May } 2021 \\ \text { Published: } & 20 \text { May } 2021\end{array}$

\section{Keywords}

Wounds, gunshot; rectum; colostomy; proctoscopy; digital rectal examination; hemostatics; conservative treatment; anti-bacterial agents; anaerobiosis; anal canal; abdominal injuries; laparoscopy; hemorrhage; tomography, x-ray computed; tomography; surgeons; colon

\section{Palabras clave:}

Trauma de recto, lesión rectal extraperitoneal, intraperitoneal, inestabilidad hemodinámica, hemodinámicamente inestable, control de daños, Heridas, recto, colostomía, proctoscopia, examen rectal digital, hemostáticos, tratamiento conservador, agentes antibacterianos, anaerobiosis, canal anal, lesiones abdominales, laparoscopia, hemorragia, tomografía, radiografía computarizada, tomografía, cirujanos colon
1 Universidad del Valle, Facultad de Salud, Escuela de Medicina, Department of Surgery, Division of Trauma and Acute Care Surgery. Cali, Colombia., 2 Hospital Universitario del Valle, Department of Surgery, Division of Trauma and Acute Care Surgery. Cali, Colombia., 3 Centro Médico Imbanaco, Cali, Colombia., 4 Universidad Icesi, Cali, Colombia, $\mathbf{5}$ Fundación Valle del Lili, Division of Colorectal Surgery, Department of Surgery, Cali, Colombia., 6 Fundación Valle del Lili. Division of Trauma and Acute Care Surgery, Department of Surgery. Cali, Colombia.., 7 Broward General Level I Trauma Center, Department of Trauma Critical Care, Fort Lauderdale, FL, USA.

\section{Abstract}

Rectal trauma is uncommon, but it is usually associated with injuries in adjacent pelvic or abdominal organs. Recent studies have changed the paradigm behind military rectal trauma management, showing better morbidity and mortality. However, damage control techniques in rectal trauma remain controversial. This article aims to present an algorithm for the treatment of rectal trauma in a patient with hemodynamic instability, according to damage control surgery principles. We propose to manage intraperitoneal rectal injuries in the same way as colon injuries. The treatment of extraperitoneal rectum injuries will depend on the percentage of the circumference involved. For injuries involving more than $25 \%$ of the circumference, a colostomy is indicated. While injuries involving less than $25 \%$ of the circumference can be managed through a conservative approach or primary repair. In rectal trauma, knowing when to do or not to do it makes the difference.

\section{Resumen}

El trauma de recto es poco frecuente, pero generalmente se asocia a lesiones de órganos adyacentes en la región pélvica y abdominal. Estudios recientes han cambiado los paradigmas del manejo tradicional derivados del trauma militar, mostrando mejores resultados en la morbilidad y mortalidad. Sin embargo, las técnicas de control de daños en el trauma rectal aún son controvertidas. El objetivo de este artículo es proponer el algoritmo de manejo del paciente con trauma rectal e inestabilidad hemodinámica, según los principios de la cirugía de control de daños. Se propone que las lesiones del recto en su porción intraperitoneal sean manejadas de la misma manera que las lesiones del colon. Mientras que el manejo de las lesiones extraperitoneales del recto dependerá del compromiso de la circunferencia rectal. Si es mayor del $25 \%$ se recomienda realizar una colostomía. Si es menor, se propone optar por el manejo conservador o el reparo primario. Saber que hacer o que no hacer en el trauma de recto marca la diferencia. 
Copyright: @ 2021 Universidad del Valle

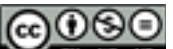

\section{Conflicts of interest:}

The authors declare that they have no conflict of interest.

\section{Acknowledgments:}

We would like to extend our gratitude to the anatomical illustrator Fabian R. Cabrera P., Professor of the Design Department of the Integrated Arts Faculty, for the illustrations and cover design. We acknowledge the contributions of Yaset Caicedo and Isabella Caicedo-Holguin for the translation of manuscript.

\section{Corresponding author:}

Carlos A. Ordonez, MD, FACS. Division of Trauma and Acute Care Surgery, Department of Surgery. Fundación Valle del Lili. Cali, Colombia; Division of Trauma and Acute Care Surgery, Department of Surgery, Universidad del Valle, Cali, Colombia; Universidad Icesi, Cali, Colombia.

e-mail: ordonezcarlosa@gmail.com, carlos.ordonez@fvl.org.co

\section{Remark}

\section{1) Why was this study conducted?}

This article aims to present an algorithm for the management of rectal trauma in the patient with hemodynamic instability, according to damage control surgery principles

\section{2) What were the most relevant results of the study?}

We propose to manage intraperitoneal rectal injuries in the same way as colon injuries. The management of extraperitoneal rectum injuries will depend on the percentage of the circumference involved. For injuries involving more than $25 \%$ of the circumference, a colostomy is indicated. While injuries involving less than $25 \%$ of the circumference can be managed through a conservative approach or primary repair.

\section{3) What do these results contribute?}

In rectal trauma, knowing when to do or not to do it makes the difference.

\section{Introduction}

Rectal trauma prevalence is low in both intraperitoneal and extraperitoneal segments. However, the intraperitoneal segment is the most commonly compromised portion. Eighty percent of rectal injuries are secondary to penetrating trauma, usually associated with other pelvic or abdominal injuries ${ }^{1}$. The principles of traditional treatment have their origins in wartime experiences. However, recent studies of civilian trauma classify extraperitoneal rectal injuries as destructive and nondestructive, depending on the percentage of circumference involved ${ }^{2,3}$. These studies have changed the paradigm behind military rectal trauma management, showing better morbidity and mortality ${ }^{2,3}$. The treatment of patients with penetrating rectal trauma and hemodynamic instability remains a surgical challenge, mainly because it requires immediate surgical exploration without allowing previous imaging studies. This article aims to present an algorithm for the treatment of rectal trauma in patients with hemodynamic instability, according to damage control surgery principles.

This article is a consensus that synthesizes the experience acquired during the last 30 years in trauma management, general surgery and critical care of the trauma and emergency surgery group (Cirugía de Trauma y Emergencias - CTE) in Cali, Colombia, conformed by experts from the Hospital Universitario del Valle "Evaristo García" and Hospital Universitario Fundación Valle del Lili with the Universidad del Valle and Universidad Icesi, in collaboration with the Colombian Association of Surgery and the Pan-American Trauma Society.

\section{Epidemiology}

According to recent reports, rectal trauma has approximately 1-3\% in civilian trauma centers and $5.1 \%$ in military scenarios. The most common mechanism is penetrating trauma secondary to gunshot wounds (71-85\%), followed by blunt trauma (5-10\%) and penetrating trauma due to stab wounds (3-5\%). An explosive mechanism causes around $23 \%$ of military rectal injuries. It is unlikely to find isolated rectal lesions due to the proximity of the rectum to other pelvic organs and blood vessels, which can make treatment very challenging. Despite significant advances in trauma systems and surgical treatment, mortality rates remain between $3-10 \%$ and the associated complications between $18-21 \%^{3-5}$. 
Table 1. Evolution Of Military Rectal Trauma Management

\begin{tabular}{lcl}
\hline Treatment & Mortality (\%) & Armed Conflict \\
\hline Non-operatory management & 100 & American Civil War (1865) \\
Primary repair & $60-90$ & World War I (1918) \\
Fecal derivation & $30-40$ & World War II (1945) \\
Fecal derivation + Pre-sacral drainage & $15-20$ & Korean War (1953) \\
Primary repair + Distal rectal lavage & $13-15$ & Vietnam War (1975) \\
Vital support + Damage control surgery & 8 & Yugoslavian War (2001) \\
\hline
\end{tabular}

Throughout history, military conflicts have significantly influenced the evolution of rectal trauma management (Table 1). Rectal trauma was managed expectantly, resulting in a mortality rate of $100 \%$ in the American Civil War; surgical treatment became mandatory with a reduction in mortality rate to $60-75 \%$ during World War I. Then, North American and British surgeons performed colostomies for colorectal injuries, with a reported mortality rate of 53-59\%, during World War II, which combined with perioperative care advances decreased mortality to $22-35 \%$. Posteriorly, in the Vietnam war, Lavenson and Cohen introduced the distal rectal lavage, which was also attributed to further decreases in the mortality rate. Finally, in Yugoslavian and Afghanistan conflicts, vital support and damage control techniques significantly reduced mortality to almost $5 \%$. Through all the experience developed during these armed conflicts, the "4 Ds" dogma (Debridement, Derivation, Drainage and Distal lavage) became the standard treatment for rectal trauma ${ }^{6-8}$.

However, several differences exist between military and civilian rectal trauma, such as injury mechanism, resource availability and the initial interventions performed. This represents a challenge reflected in high damage control surgery and mortality rates reported in the military literature. Based on a review of colorectal injuries from Iraq and Afghanistan armed conflicts, some authors advocated for derivation in rectal trauma given the unknown effects of energy dissipation from high-speed mechanisms potentially compromising the viability of an anastomosis. In civilian trauma, the optimal treatment of rectal trauma remains controversial. For this reason, it is important to acknowledge the influence of the burden placed on the combat surgeon, which might affect the extrapolation of data between civilian and military studies ${ }^{9,10}$.

In consequence, civilian trauma studies have recently questioned the " 4 Ds" principles. Stone and Fabian conducted a randomized clinical trial that reported lower mortality in patients with colon injuries managed with primary repair. These results preceded several series that assessed the efficacy of each aspect of surgical treatment in rectal trauma. The implementation of damage control techniques has introduced the second look surgeries as a second opportunity in surgical decision making.

\section{Initial approach}

The American Association for the Surgery of Trauma (AAST) anatomical classification of rectal trauma severity (Table 2) does not differentiate injuries according to their anatomical location (intraperitoneal or extraperitoneal). This situation prevents discriminating between injuries of the intraperitoneal or the extraperitoneal segment, both of which have different ma-

Table 2. AAST Rectum Trauma Classification

\begin{tabular}{lll}
\hline Grade & Injury Type & Description \\
\hline Grade & Injury Type & Description \\
& Laceration & Partial-thickness laceration \\
II & Laceration & Laceration $<50 \%$ or circumference \\
III & Laceration & Laceration $>50 \%$ of circumference \\
IV & Laceration & Full thickness laceration with extension into peritoneum \\
V & Vascular & Devascularized segment \\
\hline
\end{tabular}




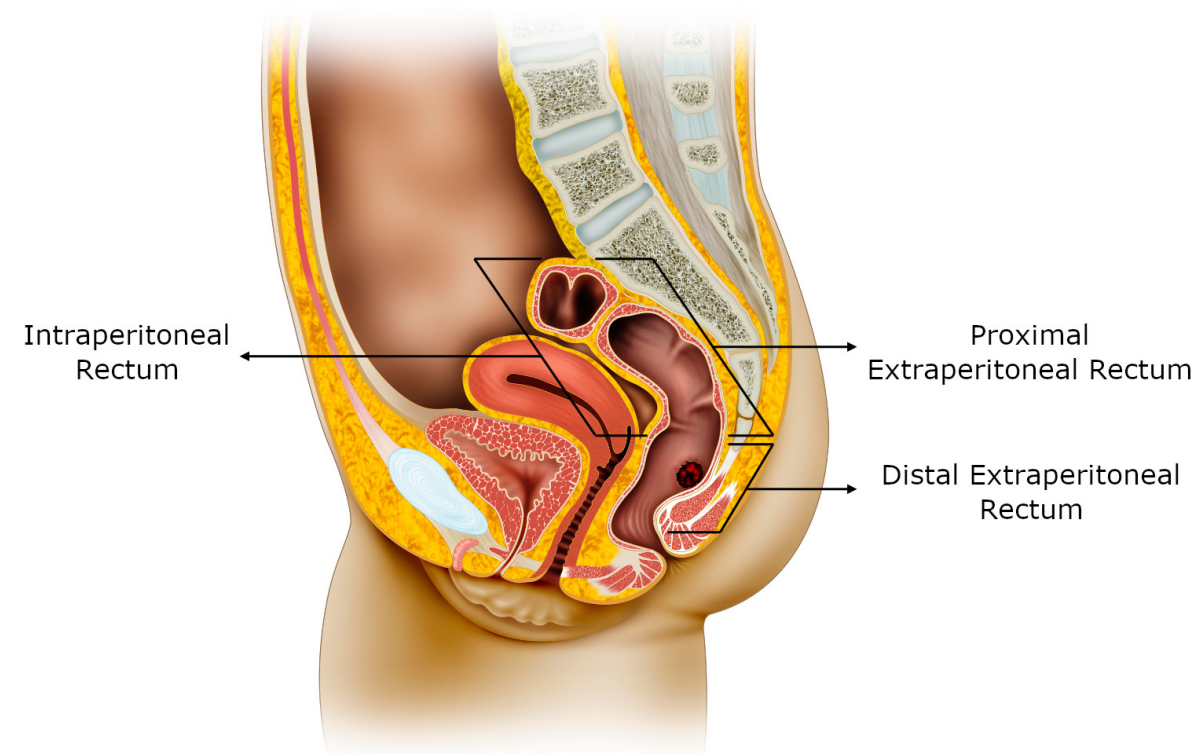

Figure 1. Anatomical Division of the Rectum: Intraperitoneal and Extraperitoneal Portions. An extraperitoneal rectal injury involving less than $25 \%$ of the circumference (nondestructive) is shown.

nagement options. Gonzales et al. introduced an alternative approach by classifying extraperitoneal rectal injuries into destructive and nondestructive according to the percentage of the rectum circumference involved, with a cut-off point of $25 \%{ }^{2}$.

The rectum is anatomically protected deep in the pelvic cavity, which makes it harder to diagnose rectal injuries (Figure 1) ${ }^{2}$. For this reason, suspicion of rectal trauma is typically raised by the mechanism of trauma and associated injuries. High energy pelvic trauma, trans-pelvic gunshot wounds and impalement mechanisms have a high probability of causing rectal injuries. Meanwhile, mechanisms such as stab wounds have a lower probability of causing rectal involvement. In the context of patients with high energy blunt trauma, a wide pubic symphysis, associated urogenital injuries and pelvic fractures (especially anteroposterior fractures by compression) should raise suspicion and guide further evaluation for concomitant rectal injuries ${ }^{11}$. Suspected rectal injuries must be evaluated through digital rectal examination, CT-Scan or proctoscopy if the patient's hemodynamic status allows it ${ }^{12}$.

\section{Digital rectal examination}

The digital rectal examination has a 33-52\% sensitivity for identifying rectal injuries, with a false positive rate of $63-67 \%$. Findings on digital rectal examination include a rectal wall defect, bleeding, decreased anal sphincter tone, bone fragments or high prostate. Macroscopic bleeding can often be confused with alternative sources, especially in large soft tissue compromise. However, a digital rectal examination still plays an important role in the confirmation of a diagnostic suspicion when there are questionable findings on physical examination. Precaution during digital rectal examination is required if it might represent a potential danger to the examiner ${ }^{13-15}$.

\section{Computed axial tomography}

Computed Axial Tomography often shows a wound track extending adjacent to the bowel. However, intraluminal contrast extravasation, a full-thickness wall defect, asymmetric extraluminal free air and hemorrhage within the bowel wall constitute more specific tomographic findings. Other imaging findings suggestive of rectal injury include rectal wall thickening, perirectal fat and intraperitoneal free fluid, which is not explained by another injury (Figure 2) ${ }^{16,17}$. 


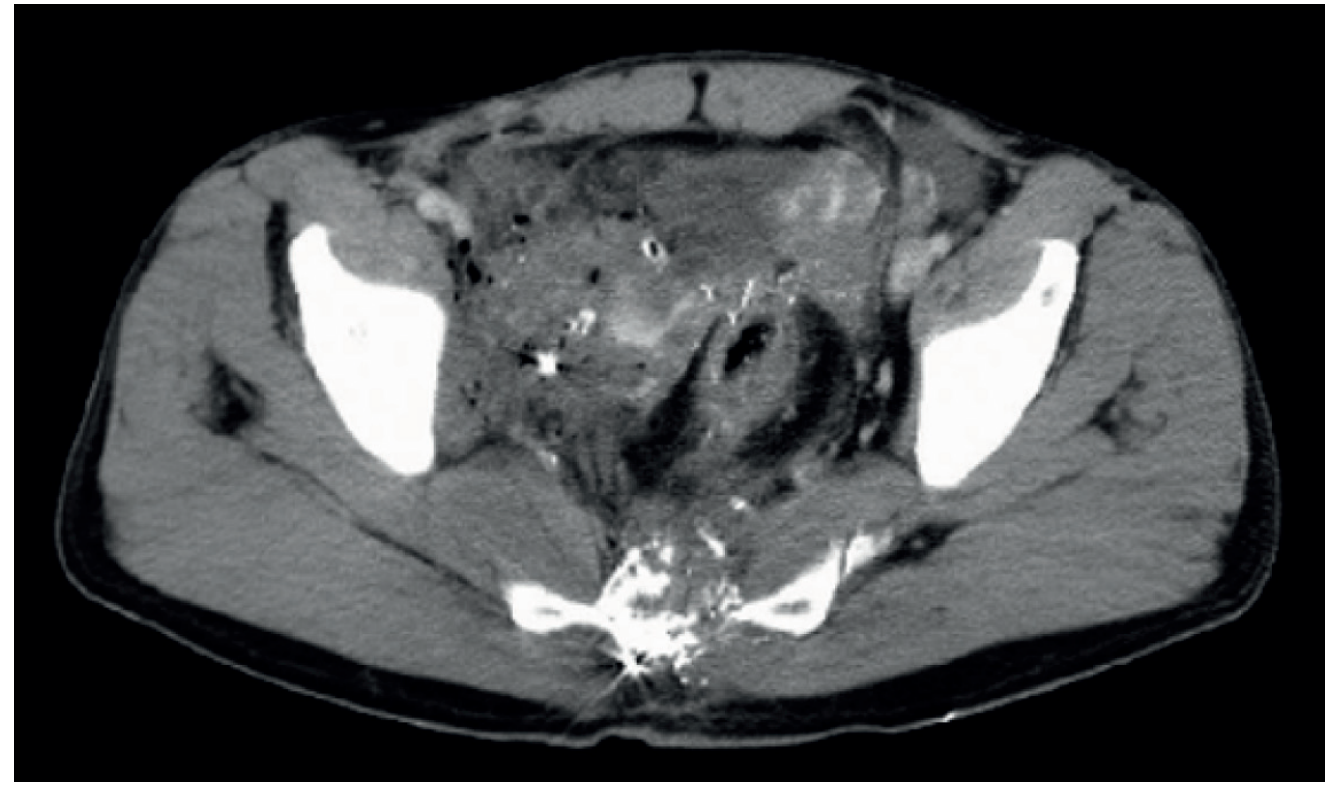

Figure 2. Computed Axial Tomography of the Upper Pelvis. Sacral fracture with several bone fragments, thickening of the rectal wall, para-rectal air and free intraperitoneal fluid are shown, in a patient with intraperitoneal rectal injury secondary to a high-speed gunshot wound in the upper quadrant of the left gluteus.

\section{Proctoscopy}

Patients with suspected rectal trauma are often evaluated with proctoscopy, which has an overall sensitivity of $71 \%$ and is even more sensitive at detecting extraperitoneal injuries (88\%). The optimal location to perform proctoscopy has been a matter of discussion. Some advocate its performance in the emergency department but, considering the poor cooperation of patients. This might decrease the examination quality. Finally, lack of bowel preparation and associated injuries may further decrease the sensitivity of proctoscopy by limiting pelvic mobility and rectal lumen visualization (bloody field) ${ }^{18}$.

\section{Surgical approach}

The treatment of patients with rectal trauma depends on their hemodynamic status and the anatomic location of the injury. Patients with hemodynamic instability should be immediately transferred to the operating room for damage control surgery, with previous hemodynamic stabilization and hemostatic resuscitation.

Intraperitoneal rectal injuries should be managed in the same way as colon injuries, in which primary repair is the standard treatment ${ }^{19}$. Colostomy constitutes an alternative when a primary repair cannot be performed. Regarding extraperitoneal rectal trauma, if the injury compromises more than de $25 \%$ of the rectal circumference (destructive injury) a colostomy is recommended. But if the injury involves less than $25 \%$ of the rectal circumference (nondestructive injury), it can be repaired.

An early administration of broad-spectrum intravenous antibiotics, guaranteeing anaerobic coverage, is crucial in the treatment of patients with rectal trauma. Antibiotics should be administered before surgical treatment and must be continued for only 24 hours postoperatively. A longer antibiotic course has shown no benefits, and extending this therapy must be considered only if there is clinical evidence of active infection. 


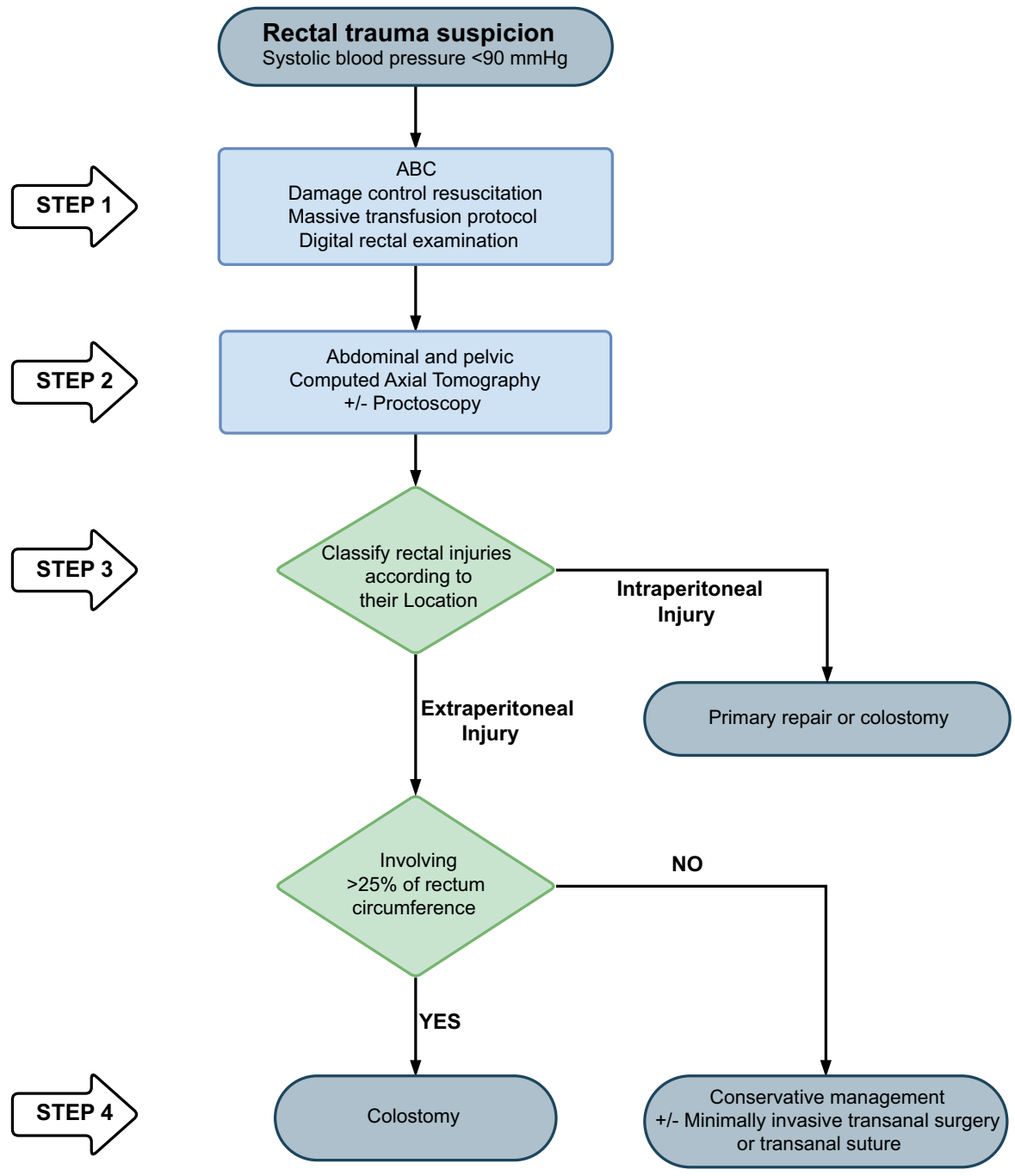

Figure 3. Damage Control Management in Rectal Trauma. An algorithm is proposed for the approach and management of the patient with suspected rectal trauma and hemodynamic instability, according to the anatomical location (intraperitoneal or extraperitoneal) of the rectal injury.

\section{Conservative management}

Patients with hemodynamic instability and extraperitoneal rectal injuries involving less than $25 \%$ of the circumference should be managed through damage control principles by omitting correction of the defect and performing serial clinical follow-up of perineal soft tissue and traumatic wounds. The transanal suture is also an initial management option if experienced surgeons and adequate equipment are available. Nonetheless, it can be performed later in the third phase of damage control.

Minimally invasive transanal surgery (MITAS) is a technique that uses basic laparoscopic equipment and is initially considered for high-quality local tumor resection. This technique has proven to be effective for local excision of tumors, but it also allows the surgeon to perform different procedures and provides direct visualization of the distal $15 \mathrm{~cm}$ of the rectum. Therefore, it has been proposed as the main strategy to repair nondestructive extraperitoneal rectal injuries ${ }^{17}$. 


\section{Colostomy}

Colostomy is a fast and effective procedure for fecal contamination control in a patient with hemodynamic instability and extraperitoneal rectal trauma involving more than $25 \%$ of the circumference.

The damage control strategy proposed for rectal trauma is outlined in the algorithm shown in Figure 3. It describes the approach and management of the patient with suspected rectal trauma and hemodynamic instability, according to the anatomical location of rectal injuries (intraperitoneal or extraperitoneal) ${ }^{13}$.

\section{Discussion}

The diagnosis of rectal injury can be challenging due to its protected anatomy. Therefore, it should be suspected based on the mechanism of trauma and injuries in adjacent structures. Trans pelvic gunshot wounds, high-energy pelvic trauma and impalement are the most common traumatic mechanisms associated with rectal injuries. Extraperitoneal rectal injuries have a high risk of going unnoticed. Therefore, it is mandatory to perform a complete evaluation of the patient (taking into account its hemodynamic status) to confirm or exclude them.

The primary repair of rectal injuries can be technically challenging due to the complex access to the pelvic cavity. Moreover, repair of posterior wounds becomes a major challenge as the rectum becomes retroperitoneal and eventually extraperitoneal. In addition, repairing injuries close to the peritoneal fold requires an extensive and time-consuming dissection which can be detrimental in patients with hemodynamic instability. In the meantime, if the injury cannot be repaired, the intraluminal contents may descend to the ischiorectal plane and ascend to the retroperitoneum ${ }^{11,18}$.

Recent studies recommend colostomy to manage extraperitoneal rectal injuries, especially if primary repair is not technically feasible ${ }^{20,21}$. On the other hand, some intraperitoneal rectal injuries can be repaired primarily without performing a colostomy ${ }^{21}$. Accordingly, we have proposed a simplified damage control management for rectal trauma, which avoids time-consuming interventions such as pre-sacral drainage or rectal lavage. Interventions, that have no negative impact in morbidity and mortality ${ }^{11}$.

\section{References}

1. Steele SR, Maykel JA, Johnson EK. Traumatic injury of the colon and rectum: the evidence vs dogma. Dis Colon Rectum. 2011; 54(09):1184-1201. doi: 10.1007/DCR.0b013e3182188a60.

2. Gonzalez RP, Phelan H III, Hassan M, Ellis CN, Rodning CB. Is fecal diversion necessary for nondestructive penetrating extraperitoneal rectal injuries? J Trauma. 2006;61(04):815-819. doi: 10.1097/01. ta.0000239497.96387.9d.

3. Brown SR, Swisher JP, Hofmann LJ, Coviello LC, Davis KG. Surgical management and associated complications of penetrating rectal injuries sustained in Iraq and Afghanistan. Mil Med. 2013; 178(11):1213-1217. doi: 10.7205/MILMED-D-13-00167.

4. Glasgow SC, Steele SR, Duncan JE, Rasmussen TE. Epidemiology of modern battlefield colorectal trauma: a review of 977 coalition casualties. J Trauma Acute Care Surg. 2012;73(06, Suppl 5): S503-S508. doi: 10.1097/TA.0b013e3182754759.

5. Cho SD, Kiraly LN, Flaherty SF, Herzig DO, Lu KC, Schreiber MA. Management of colonic injuries in the combat theater. Dis Colon Rectum. 2010;53(05):728-734. doi: 10.1007/DCR.0b013e3181d326fd. 
6. Steele SR, Wolcott KE, Mullenix PS, Martin MJ, Sebesta JA, Azarow KS, et al. Colon and rectal injuries during Operation Iraqi Freedom: are there any changing trends in management or outcome?. Dis Colon Rectum. 2007;50(06):870-877. doi: 10.1007/s10350-007-0235-4.

7. Duncan JE, Corwin CH, Sweeney WB, Dunne JR, Denobile JW, Perdue PW, et al. Management of colorectal injuries during operation Iraqi freedom: patterns of stoma usage. J Trauma. 2008;64(04):1043-1047. doi: 10.1097/TA.0b013e318047c064.

8. Shannon FL, Moore EE, Moore FA, McCroskey BL. Value of distal colon washout in civilian rectal trauma-reducing gut bacterial translocation. J Trauma. 1988;28(07):989-994. doi: 10.1097/00005373-198807000-00013.

9. DeBakey ME. Military surgery in World War II; a backward glance and a forward look. N Engl J Med. 1947;236(10):341-350. doi: 10.1056/NEJM194703062361001.

10. Stone HH, Fabian TC. Management of perforating colon trauma: randomization between primary closure and exteriorization. Ann Surg. 1979;190(04):430-436. doi: 10.1097/00000658-197910000-00002.

11. Weinberg JA, Fabian TC, Magnotti LJ, Minard G, Bee TK, Edwards N, et al. Penetrating rectal trauma: management by anatomic distinction improves outcome. J Trauma. 2006; 60(3):508-514. doi: 10.1097/01. ta.0000205808.46504.e9.

12. Bosarge PL, Como JJ, Fox N, Falck-Ytter Y, Haut ER, Dorion HA, et al. Management of penetrating extraperitoneal rectal injuries: An Eastern Association for the Surgery of Trauma practice management guideline. $J$ Trauma Acute Care Surg. 2016; 80(3):546-51. doi: 10.1097/TA.0000000000000953.

13. Esposito TJ, Ingraham A, Luchette FA, Sears BW, Santaniello JM, Davis KA, et al. Reasons to omit digital rectal exam in trauma patients: no fingers, no rectum, no useful additional information. J Trauma. 2005; 59(6): 1314-1319. doi: 10.1097/01.ta.0000198375.83830.62.

14. Hargraves MB, Magnotti LJ, Fischer PE, Schroeppel TJ, Zarzaur BL, Fabian TC, et al. Injury location dictates utility of digital rectal examination and rigid sigmoidoscopy in the evaluation of penetrating rectal trauma. Am Surg. 2009; 75(11):1069-1072. doi: 10.1177/000313480907501108.

15. Shlamovitz GZ, Mower WR, Bergman J, Crisp J, DeVore HK, Hardy D, et al. Poor test characteristics for the digital rectal examination in trauma patients. Ann Emerg Med. 2007; 50(1): 25-33. doi: 10.1016/j.annemergmed.2007.01.022.

16. Johnson EK, Judge T, Lundy J, Meyermann M. Diagnostic pelvic computed tomography in the rectal-injured combat casualty. Mil Med. 2008;173(3):293-299. doi: 10.7205/milmed.173.3.293.

17. Anderson SW, Soto JA. Anorectal trauma: the use of computed tomography scan in diagnosis. Semin Ultrasound CT MR. 2008; 29(06):472-482. doi: 10.1053/j.sult.2008.10.004.

18. Schellenberg, M, Inaba K, Priestley EM, Durso J, Wong MD, Lam L, et al. The diagnostic yield of commonly used investigations in pelvic gunshot wounds. J Trauma Acute Care Surg. 2016; 81(4): 692-8. doi: 10.1097/ TA.0000000000001159.

19. Ordoñez CA, Parra M, Caicedo Y, Padilla N, Angamarca E, Serna J, et al.. Damage control surgical management of combined small and large bowel injuries in penetrating trauma: Are ostomies still pertinent? Colomb Med (Cali). 2021;52(2): e4114425. Doi: 10.25100/cm.v52i2.

20. Ahern DP, Kelly ME, Courtney D, Rausa E, Winter DC. The management of penetrating rectal and anal trauma: A systematic review. Injury. 2017; 48(6): 1133-8. doi: 10.1016/j.injury.2017.03.002.

21. Atallah S, Albert M, De Beche-Adams T, Larach S. Transanal minimally invasive surgery (TAMIS): Applications beyond local excision. Tech Coloproctol. 2013; 17(2): 239-43. doi: 10.1007/s10151-012-0945-z. 